\title{
TERRITORIAL ANALYSIS OF AGRICULTURAL GREENHOUSE GAS EMISSION IN POLAND
}

\author{
WÓJCIK-GRONT, E. ${ }^{1} *$ \\ ${ }^{1}$ Warsaw University of Life Sciences - SGGW, Warsaw, Poland \\ ul. Nowoursynowska 159 \\ 02-776 Warszawa \\ (phone: +48-22-59-327-21; fax: +48-22-59-327-22) \\ *Corresponding author \\ e-mail: ewojcik.gront@gmail.com \\ (Received 21 $1^{\text {st }}$ Oct 2014; accepted $1^{\text {st }}$ Dec 2014)
}

\begin{abstract}
Poland is obliged to report GHG emission annually in the form of the National Greenhouse Gas Inventory Report (NIR) to the secretariat of the United Nations Framework Convention on Climate Change (UNFCCC). The Intergovernmental Panel on Climate Change (IPCC) methodology was adopted to estimate Polish GHG emission. One of the sectors is agriculture, where $\mathrm{CH}_{4}$ and $\mathrm{N}_{2} \mathrm{O}$ emission was calculated. Poland is divided into 16 voivoideships which are administrative subdivisions. In this paper total agricultural emission in all the voivoideships is estimated starting from 2000 to 2012. The biggest emission was estimated for Mosovian (MA) voivoideship and accounted for $532.7 \mathrm{Gg} \mathrm{CO}_{2}$-eq in 2000and $572.0 \mathrm{Gg} \mathrm{CO}_{2}$-eq in 2012. The smallest emission was estimated for Lubusz (LB) voivoideship and was equal to $35.1 \mathrm{Gg} \mathrm{CO}_{2}$-eq in 2000 and $31.8 \mathrm{Gg} \mathrm{CO}_{2}$ eq in 2012 .
\end{abstract}

Keywords: methane, nitrous oxide, uncertainty, climate change, mitigation

\section{Introduction}

Greenhouse gases affect the atmosphere by chemical changes and therefore can cause climate change (IPCC, 2007). One of the greenhouse gases (GHG) is methane, that was estimated to contribute $3.3 \mathrm{GtCO}_{2}$-eq/year of global anthropogenic emissions in $2005(6.5 \%)$ and nitrous oxide with $2.8 \mathrm{GtCO}_{2}$-eq/year (5.5\%) (Smith et al., 2007). As a way to assess the potential climate change associated with different GHG gases Global Warming Potential (GWP) was introduced (Lashof and Ahuja, 1990). It depends on gas's absorption of radiation, its absorbing wavelengths and its lifetime in the atmosphere. Global Warming Potential (GWP) of $\mathrm{CH}_{4}$ is $21 \mathrm{CO}_{2}$-eq and $310 \mathrm{CO}_{2}$-eq for $\mathrm{N}_{2} \mathrm{O}$ in 100 years time horizon (IPCC, 2006). It means that the warming potential of $\mathrm{CH}_{4}$ is 21 higher than $\mathrm{CO}_{2}$ in 100 years time horizon. Concentration of $\mathrm{N}_{2} \mathrm{O}$ in the atmosphere is lower but its GWP is almost 15 times higher than $\mathrm{CH}_{4}$. Using GWP emission values for different gases might be presented as $\mathrm{CO}_{2}$-eq. One of the GHG emissions sources is agriculture. According to IPCC assumptions this sector is responsible for $\mathrm{CH}_{4}$ and $\mathrm{N}_{2} \mathrm{O}$ emission. $\mathrm{CO}_{2}$ is also emitted but this is covered by other sectors. Its overall methane and nitrous oxide emission is estimated to constitute global estimated emission in over $10 \%$. Agriculture is the world's biggest emitter of methane $(\sim 50 \%)$ and nitrous oxide ( $\sim 60 \%)$ that comes from anthropogenic sources (Smith et al., 2007). In agricultural sector most of methane is expelled as a byproduct from enteric fermentation (Crutzen, 1986; Kennedy and Milligan, 1978; Murray et al., 1976). Methane is also emitted from manure management that consists of manure capture, storage, handling and utilization (Mosieret et al., 1998). Nitrous oxide is emitted mostly 
from agricultural soils and also from manure management (Oenema et al., 2005; Smith and Conen, 2004).

The aim of this paper is to calculate methane and nitrous oxide emission from agriculture in the 16 voivodeships of Poland. These subdivisions (voivodeships) were created based on Polish local government reforms in 1998 and started up in 1999. This is why the year 2000 was taken as a starting point of this analysis. According to the size from the biggest to the smallest one there are following voivoideships in Poland: Masovian (MA, 11.37\%), Greater Poland (WP, 9.54\%), Lublin (LU, 8.03\%), Warmian-Masurian (WM, 7.74\%), West Pomeranian (ZP, 7.32\%), Podlaskie (PD, 6.46\%), Lower Silesian (DS, 6.38\%), Pomeranian (PM, 5.85\%), Łódź (LD, 5.83\%), Kuyavian-Pomeranian (KP, 5.75\%), Podkarpackie (PK, 5.71\%), Lesser Poland (MP, 4.86\%), Lubusz (LB, 4.47\%), Silesian (SL, 3.94\%), Świętokrzyskie (SW, 3.74\%), Opole (OP, 3.01\%).

Population density (population per $\mathrm{km}^{2}$ ) in the voivodeships is as follows starting from the highest: Silesian (SL, 374.3), Lesser Poland (MP, 220.9), Masovian (MA, 149.1), Lower Silesian (DS, 146.1), Łódź (LD, 138.6), Pomeranian (PM, 125.1) Podkarpackie (PK, 119.4), Kuyavian-Pomeranian (KP, 116.7), Greater Poland (WP, 116.1), Świętokrzyskie (SW, 108.8), Opole (OP, 107.3), Lublin (LU, 86.2), West Pomeranian (ZP, 75.2), Lubusz (LB, 73.2), Warmian-Masurian (WM, 60.0), Podlaskie (PD, 59.4).

Polish GHG emission is reported annually to the secretariat of the United Nations Framework Convention on Climate Change (UNFCCC) as the National Greenhouse Gas Inventory Report (NIR). According to the calculations conducted in compliance to the IPCC methodology (IPCC 1997) agriculture was responsible for $10 \%$ of Polish total GHG emission in 2000 and in 2012 (NIR 2014) (Fig.1). This makes agriculture second IPCC emitter in Poland, right after Energy, sector that is responsible for over $85 \%$ of GHG emission from anthropogenic sources.

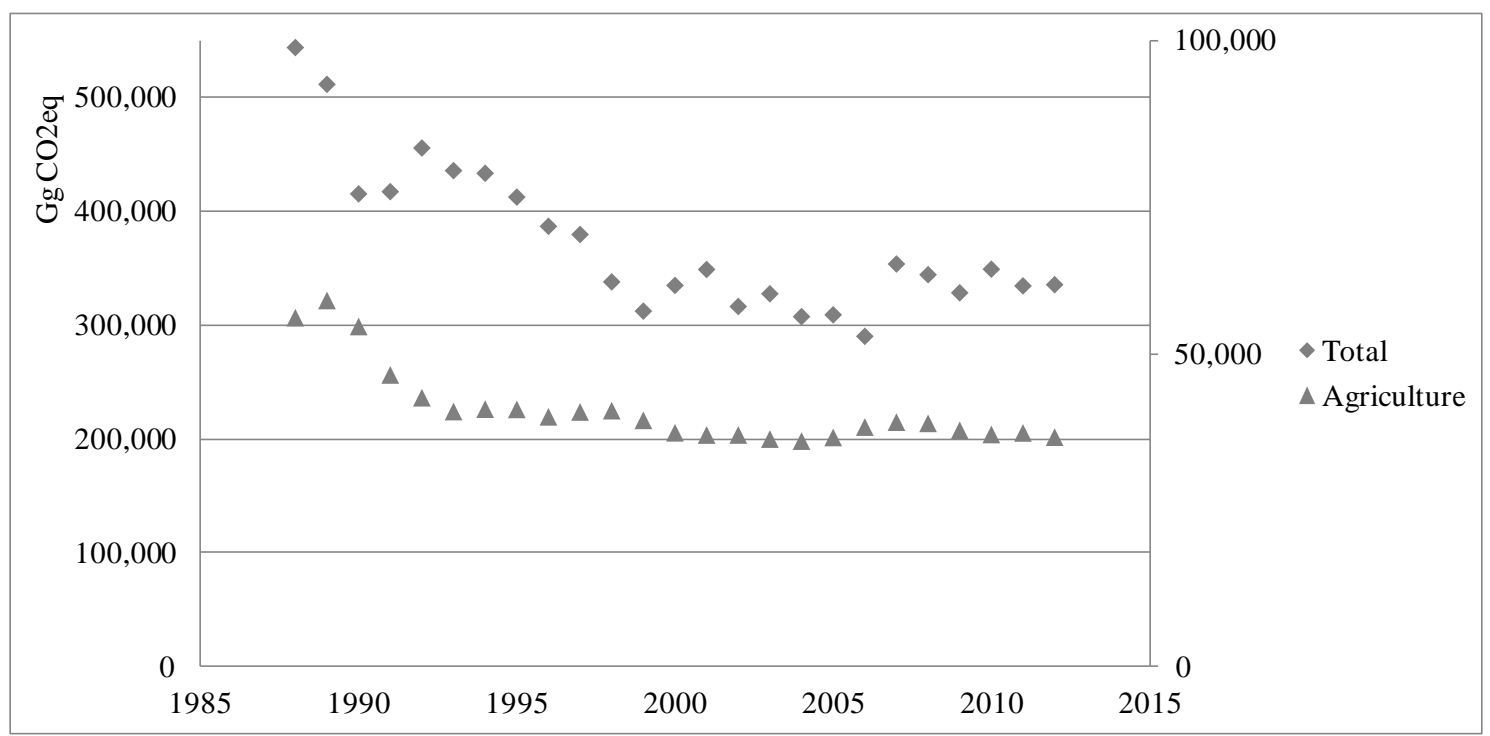

Figure 1. Polish total and agricultural emission $\mathrm{Gg}_{\mathrm{CO}}$-eq from 1988 to 2012 (NIR 2014).Left scale applies to total Polish emission, while the right only to agricultural emission.

Total Polish GHG emission reported to UNFCCC was lower in 2012 in comparisons to years before 2000 and accounted for $367413 \mathrm{GgCO}_{2}$-eq. Agricultural GHG emission was equal to $36654 \mathrm{GgCO}_{2}$-eq in 2012. It seems that from 2000 the total emission as well as agricultural emission in Poland stay almost at the same level (Fig.1). 
In 2004 there was Polish adhesion to European Union. The structure of Polish farms changed and was caused by EU agricultural subventions. However, the biggest change had started even before with the end of communism period in 1989, when Polish economy had started changing from centrally planned to free market. State-own collective farms were privatisated, herds were reduced, and selling milk of low quality was forbidden. It caused GHG emission reduction in agriculture (Fig. 1). Now private farms are more specialized, modernized, that makes them more effective.

In Poland agricultural GHG emission sources contain enteric fermentation, manure management from livestock production, agricultural soils and field burning of agricultural residues. Emission from agricultural soils consist of emission from synthetic fertilizers use, animal manure applied to soils, cultivation of $\mathrm{N}$-fixing crops, incorporating crop residues after harvest, cultivation of histosols, sewage sludge applied to fields, pasture, range and paddock manure, atmospheric deposition, nitrogen leaching and run-off (Fig. 2).

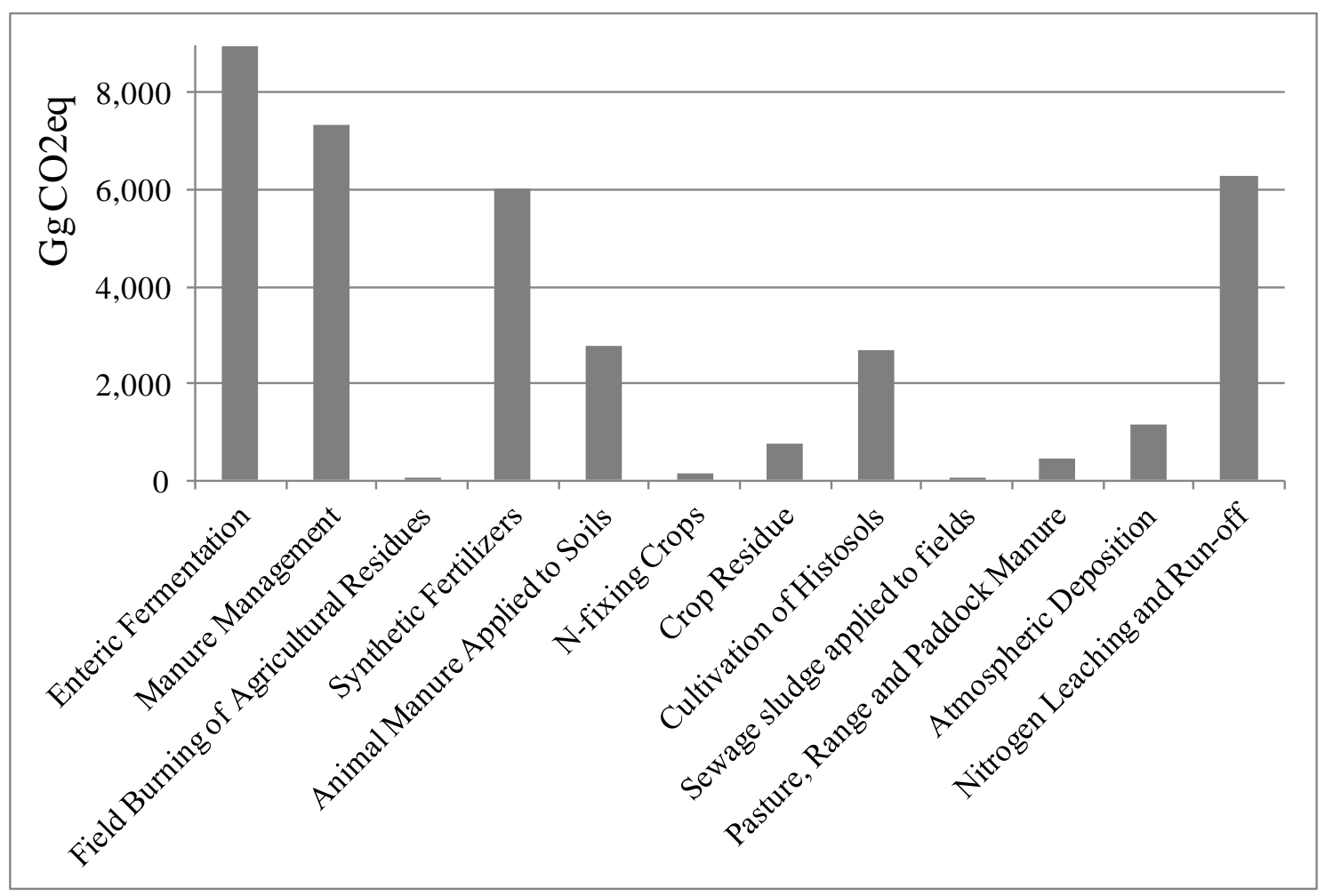

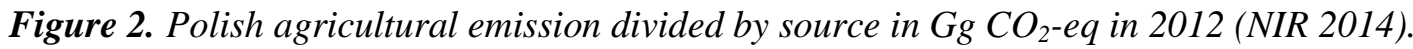

Enteric fermentation is responsible for most methane emission, manure management and field burning of agricultural residues commits to methane and nitrous oxide emission and agricultural soils is main nitrous oxide emitter. Agricultural methane emission accounted for over $26 \%$ of total net methane emission estimated for Poland excluding land use, land-use change and forestry (LULUCF), the sector that contributes to emission reduction by absorption. More than $78 \%$ of agricultural methane emission comes from enteric fermentation. Agricultural nitrous oxide emission accounted for over $83 \%$ of total net nitrous oxide emission estimated for Poland. More than $80 \%$ of agricultural nitrous oxide emission comes from agricultural soils. Manure management 
constitutes over one fifth of agricultural methane emission and almost as much of agricultural nitrous oxide emission.

\section{Materials and Methods}

Voivoideship emission was estimated based on IPCC methodology (IPCC 1997; IPCC 2000). In general emission is calculated as an activity multiplied by its emission factor. Activity is defined as a number of animals by type living in a voivoideship in a specific year (for example, the number of horses in 2012). The emission factor is the amount of greenhouse gas produced annually by the activity: for example, the amount of methane from manure management in sheep for 2012. Emission factors were the same for all voivoideships. Neither activities nor emission factors are known precisely. When conversion of the amount of specific gas (methane or nitrous oxide) into $\mathrm{CO}_{2}$ emission equivalent $\left(\mathrm{CO}_{2}\right.$-eq) is done the emissions from all sources in agriculture are summed to voivodeship agricultural emission in a specific year.

The methodology enumerates several domestic animals. In Poland this methodology applies to: dairy cattle, non-dairy cattle, sheep, goats, horses, swine and poultry. Enteric fermentation applies to all ruminants, horses and swine. Manure management applies to all animals.

Revised IPCC Guidelines for National Greenhouse Gas Inventories from 1996 (IPCC 1997) allow two approaches to estimate emission factor for enteric fermentation. One (Tier 1) is simplified and relies on default emission factors for all animals. The other one (Tier 2) uses country specific data on animal and feed characteristic. In Polish NIR Tier 2 methodology was used for estimating the emission factor from enteric fermentation in case of cattle and sheep. For goats, horses and swine default emission factors were used. They are the same for all years. Equation for methane emission factor for enteric fermentation in Tier 2 approach takes into account average daily feed intake $\mathrm{MJ} / \mathrm{h}$ ead/day, that depends on energy required for maintenance, activity, lactation, work, growth, wool production and pregnancy of a type of animal and methane conversion rate that is the fraction of feed energy converted to methane. Methane emission factors for enteric fermentation were calculated separately for dairy cattle, non-dairy cattle as a weighted mean of calves under 1 year, 1-2 year animals and older than 2 year, sheep as a weighted mean of lambs up to 1 year and older sheep. Methane emission factors for animals calculated according to Tier 2 methodology during years 2000-2012 have a tendency do increase due to changes in their diet. For example in case of dairy cattle in 2000 it was $90.8 \mathrm{~kg} \mathrm{CH}_{4} / \mathrm{head} /$ year and constant increase caused it to be 99.6 in 2012. The default values in IPCC Tier 1 methodology are lower $(81 \mathrm{~kg}$ $\mathrm{CH}_{4} /$ head/year). In most cases the difference from IPCC default values appears due to differences in animal age structure between regions where the factors are calculated.

Methane emission factor for non-dairy cattle has also increased from $2000(44.2 \mathrm{~kg}$ $\mathrm{CH}_{4} /$ head/year) to 2012 by around $4 \%$ but it depends much on non-dairy cattle age structure and there are years when it was lower than in 2000 (IPCC default value is 56 $\mathrm{kg} \mathrm{CH} /$ animal/year). In case of sheep methane emission factor varied from $7.82 \mathrm{~kg}$ $\mathrm{CH}_{4} /$ head/year in 2003 up to $8.21 \mathrm{~kg} \mathrm{CH}_{4} / \mathrm{head} /$ year in 1999 (IPCC default value is $8 \mathrm{~kg}$ $\mathrm{CH}_{4}$ /animal/year).

Estimation of methane and nitrous oxide from manure management can also be done in two ways using default emission factors from Tier 1 methodology or calculated based on equations from Tier 2 methodology. Methane emission factor for manure 
management depends on excreted by an animal solids, $\mathrm{CH}_{4}$ production capacity for manure produced by animal, methane conversion factors for manure management system. Nitrous oxide emission factor for manure management depends on emission factor per animal waste management system, where default values were used as well as calculated nitrogen excretion per animal type.

Nitrous oxide emitted from agricultural soils is estimated based on data on the amount of nitrogen synthetic fertilizer applied to agricultural fields, livestock by type, $\mathrm{N}$-fixing crops yields, crop production, estimated agricultural lands cultivated and/or irrigated and amount of sewage sludge applied on the fields. The emission factors for nitrous oxide agricultural soils emission were taken from IPCC1997.

The amount of methane and nitrous oxide emission from field burning of agricultural residues was calculated based on activity data on crop production and default emission factors (IPCC 1997).

All the activity data regarding the amount of Polish livestock by type, fertilizers, plant yields, agricultural lands cultivated, sewage sludge were taken from Polish Central Statistical office: "Statistical yearbook on agriculture" and "Environment" (GUS 20002012). The uncertainty of the data is estimated to be $5 \%-30 \%$ of the activity and between 30 to $150 \%$ of emission factor. The uncertainty of results were calculated according to the report "Good practice Guidance and Uncertainty Management in National Greenhouse Gas Inventories (IPCC 2000) using a simplified method with error propagation equations. In this method uncertainty of emission from one source $\left(\mathrm{U}_{\mathrm{EM} \_}\right)$, for example from synthetic fertilizer use, is calculated from equation 1 using uncertainty associated with activity and emission factor. Uncertainty emission of the whole agricultural sector is calculated from equation 2. In the equations $U$ are the percentage uncertainty of the values and $\mathrm{x}$ are the uncertain values.

$$
\begin{gathered}
U_{E M_{-} i}=\sqrt{U_{A c t_{-} i}^{2}+U_{E F_{-} i}^{2}} \\
U_{E M_{-} t o t}=\frac{\sqrt{\left(U_{E M_{-} 1} \cdot x_{E M_{-} 1}\right)^{2}+\left(U_{E M_{-} 2} \cdot x_{E M_{-} 2}\right)^{2}+\ldots+\left(U_{E M_{-} n} \cdot x_{E M_{-} n}\right)^{2}}}{x_{E M_{-} 1}+x_{E M_{-} 2}+\ldots+x_{E M_{-} n}}
\end{gathered}
$$

The same method was used in Polish inventory report NIR in 2014. Studies by Wójcik-Gront and Gront (2014) showed that this method of assessing uncertainty is sufficient for this kind of study.

\section{Results and Discussion}

The results on agricultural emission in 16 Polish voivodeships for 2012 are presented in Fig. 3 and Fig. 4. The map was created using Bioshell package (Gront and Koliński, 2006, 2008). In the Table 1 the results for years 2012, 2006 and 2000 are compared. These years were chosen to present the voivodeship agricultural emission character. But the results are not that different for other years. The data are presented as $\mathrm{CO}_{2}$ equivalents per $100 \mathrm{~km}^{2}$. The more agricultural region the highest emission is remarked. 


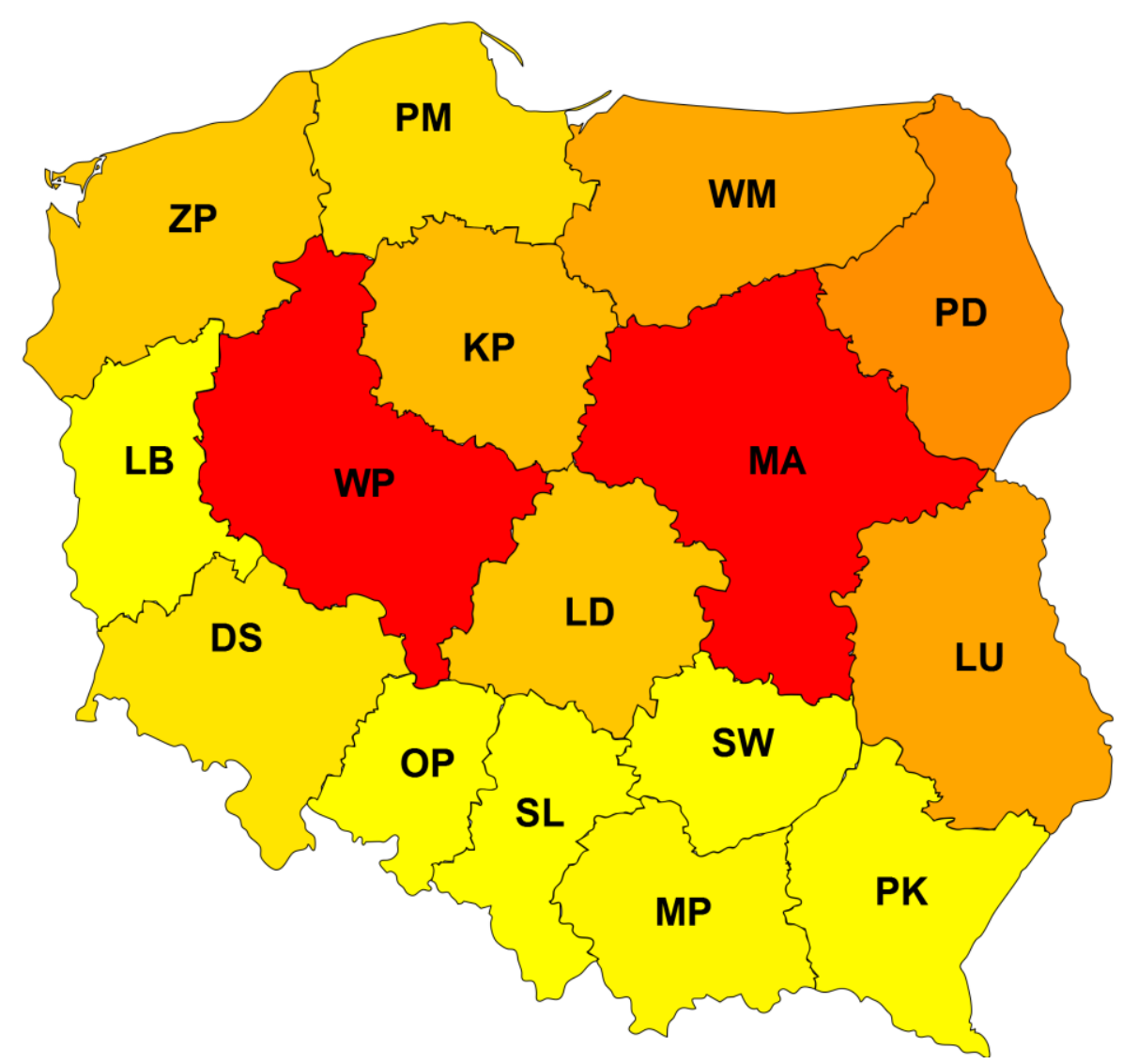

Figure 3. The map of agricultural emission per area in Polish voivodeships.

Table 1. Agricultural emission in 2012, 2006 and 2000in $\mathrm{Gg} \mathrm{CO}_{2}$-eq per $100 \mathrm{~km}^{2}$.

\begin{tabular}{c|c|c|c}
\hline & \multicolumn{3}{|c}{ Emission in Gg CO $\mathbf{C O}_{\mathbf{2}}$-eq per 100km } \\
\hline Voivodeship & $\mathbf{2 0 0 0}$ & $\mathbf{2 0 0 6}$ & $\mathbf{2 0 1 2}$ \\
\hline Lubusz (LB) & 35 & 33 & 32 \\
Silesian (SL) & 39 & 34 & 33 \\
Opole (OP) & 34 & 35 & 35 \\
Świętokrzyskie (SW) & 48 & 43 & 35 \\
Podkarpackie (PK) & 80 & 60 & 40 \\
Lesser Poland (MP) & 87 & 68 & 48 \\
Lower Silesian (DS) & 78 & 75 & 85 \\
Pomeranian (PM) & 106 & 99 & 100 \\
West Pomeranian (ZP) & 163 & 143 & 144 \\
Lódź (LD) & 154 & 166 & 151 \\
Kuyavian-Pomeranian (KP) & 175 & 190 & 174 \\
Warmian-Masurian (WM) & 184 & 211 & 212 \\
Lublin (LU) & 247 & 246 & 219 \\
Podlaskie (PD) & 218 & 245 & 268 \\
Greater Poland (WP) & 526 & 569 & 572 \\
Masovian (MA) & 533 & 605 & 572 \\
\hline
\end{tabular}

The highest emission per area in this period was in Masovian (MA) and Greater Poland (WP) voivodeships. In 2012 the agricultural emission in these regions were almost the same and accounted for around $572 \mathrm{CO}_{2}-\mathrm{eq} / 100 \mathrm{~km}^{2}$. These are the biggest 
voivodeships in Poland. They are known as the biggest Polish agricultural producers. The second group with emission from 85.5 to $267.8 \mathrm{CO}_{2}$-eq $/ 100 \mathrm{~km}^{2}$ constitute voivodeships: Lower Silesian (DS), Pomeranian (PM), West Pomeranian (ZP), Lódź (LD), Kuyavian-Pomeranian (KP), Warmian-Masurian (WM), Lublin (LU), Podlaskie (PD). The lowest emission $\left(31.8-48.3 \mathrm{CO}_{2}\right.$-eq $\left./ 100 \mathrm{~km}^{2}\right)$ was obtained in regions with high population density, the most industrialized, the most urbanized region in Poland (Lubusz (LB), Silesian (SL), Opole (OP) voivodeships) or in mountain region (Świętokrzyskie (SW)). The total agricultural emission uncertainty in the voivodeships is $\pm 42.3 \%$.

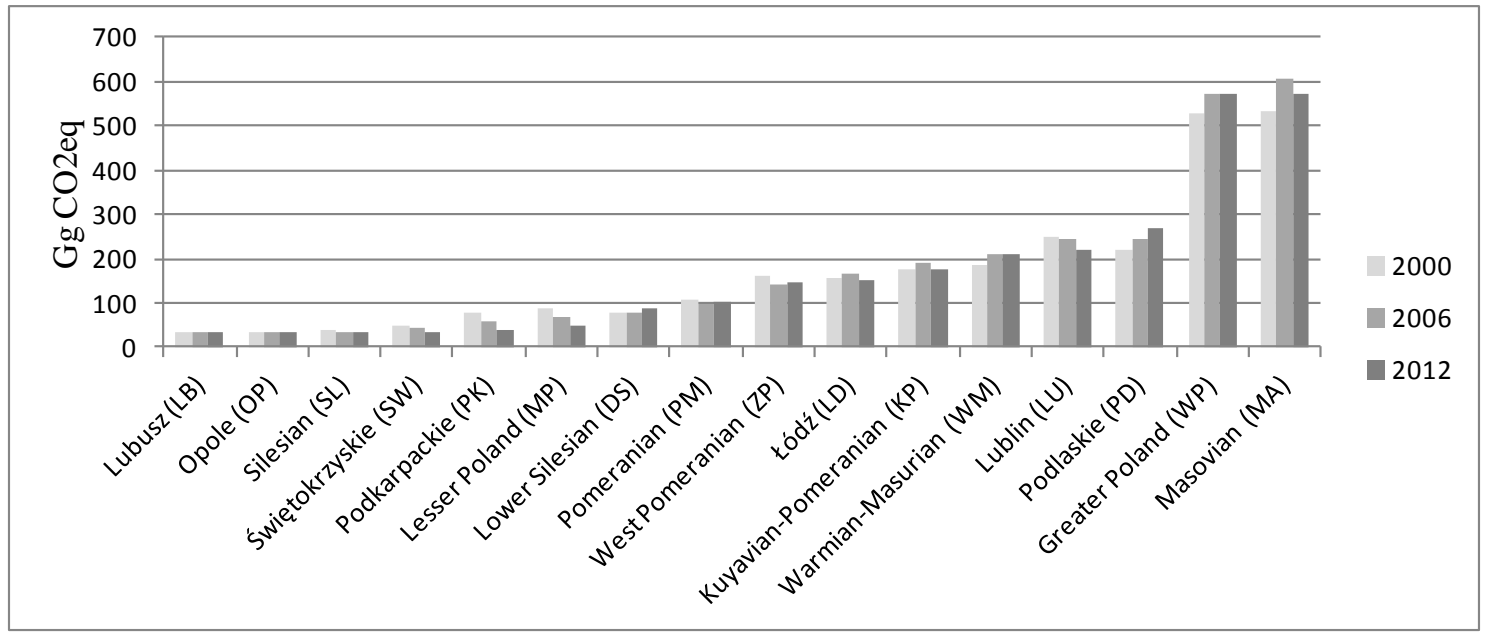

Figure 4. Total agricultural emission in $\mathrm{CO}_{2}$-eq per $100 \mathrm{~km}^{2}$ in Polish voivodeships in 2000, 2006 and 2012.

Results on emission per area in a voivodeship depend mostly on area of agricultural soils the main source of nitrous oxide emission (Fig. 5). This is the most influential emission source because, as it was mentioned in the Introduction, nitrous oxide GWP is $310 \mathrm{CO}_{2}$-eq.



Figure 5. Total methane and nitrous oxide agricultural emission in $\mathrm{CO}_{2}$-eq per $100 \mathrm{~km}^{2}$ in Polish voivodeships in 2012. 
The total agricultural emission depends also on agricultural $\mathrm{CH} 4$ emission. The $\mathrm{CH} 4$ emission consist mostly of enteric fermentation emission then manure management emission and in a very small amount emission from field burning of agricultural residues (Fig. 6). The emission from enteric fermentation depends mostly on the amount of animal living in a voivodeship in a specific year and on the animal structure. The highest percentage of enteric fermentation share in total methane emission in a voivodeship in 2012 is in Podlaskie 87\%. This voivodeship has high amount of dairy cattle, where the emission factor for enteric fermentation is the highest. The lowest share is in Greater Poland 68\%. In all voivodeships the emission from field burning of agricultural residues is around $1 \% / 100 \mathrm{~km}^{2} /$ year of total agricultural methane emission. Average emission in voivodeships from manure management in $23 \%$ of total agricultural $\mathrm{CH}_{4}$ emission per area in a voivodeship.

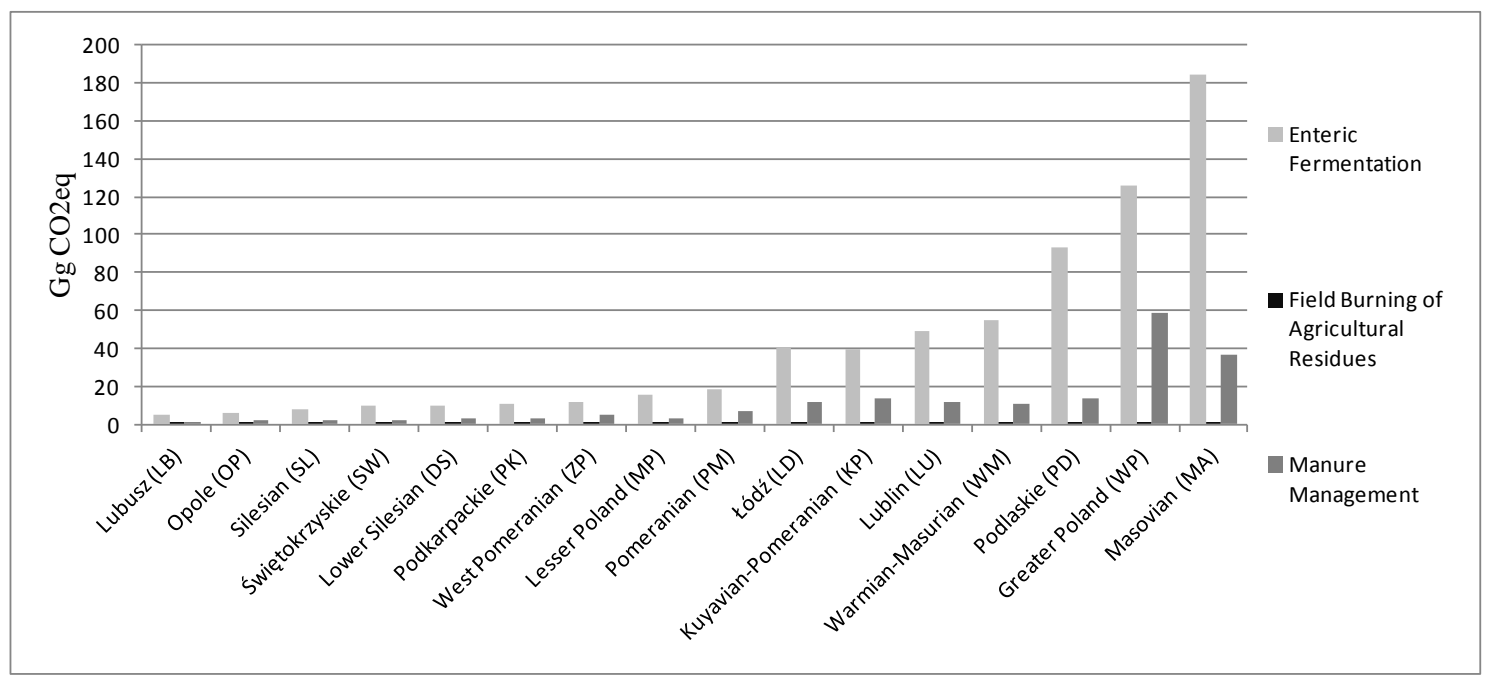

Figure 6. Methane agricultural emission in $\mathrm{CO}_{2}$-eq per $100 \mathrm{~km}^{2}$ in Polish voivodeships in 2012 broken down into sources.

In case of nitrous oxide there are many emission sources: animal manure applied to soils, atmospheric deposition, crop residue, cultivation of histosols, field burning of agricultural residues, manure management, $\mathrm{N}$-fixing crops, nitrogen leaching, pasture, range and paddock manure, sewage and synthetic fertilizers.

The highest N2O emission from agriculture per area was in Greater Poland (WP) voivodeship and accounted for $386.4 \mathrm{Gg} \mathrm{CO}_{2}$-eq per $100 \mathrm{~km}^{2}$ in 2012 . The structure was a follows: animal manure applied to soils $-14 \%$, atmospheric deposition $-5 \%$, crop residue $-3 \%$, cultivation of histosols $-3 \%$, field burning of agricultural residues $-0 \%$, manure management $-24 \%$, $\mathrm{N}$-fixing crops $-1 \%$, nitrogen leaching $-26 \%$, pasture, range and paddock manure $-2 \%$, sewage $-0 \%$ and synthetic fertilizers $-23 \%$. The lowest $\mathrm{N} 2 \mathrm{O}$ emission from agriculture per area was in Silesian (SL) voivodeship and accounted for $386.4 \mathrm{Gg} \mathrm{CO}_{2}$-eq per $100 \mathrm{~km}^{2}$ in 2012 . The structure is similar to Greater Poland (WP) voivodeship one.

It should be stated that, in all voivodeships the total agricultural emission estimate is more than $40 \%$. The main source of the uncertainty in is the great uncertainty in emission factors (especially nitrous oxide up to 150\%) which sometimes is to the nature of the phenomenon. 


\section{REFERENCES}

[1] Crutzen, P., Aselmann, I., Seiler W. (1986): Methane production by domestic animals, wild ruminants, and other herbivorous fauna and humans - Tellus 38B, 271.

[2] Gront, D., Kolinski, A. (2008): Utility library for structural bioinformatics Bioinformatics 24(4): 584-585.

[3] Gront, D., Kolinski, A. (2006): BioShell - a package of tools for structural biology computations - Bioinformatics 22(5):621-622.

[4] GUS (2000-2012): Central Statistical Office, Statistics of Poland, website: http://stat.gov.pl/en/ "Statistical yearbook on agriculture" and "Environment"

[5] IPCC (1997). Revised 1996 IPCC Guidelines for National Greenhouse Gas Inventories. IPCC 1997.

[6] IPCC (2000). Good Practice Guidance and Uncertainty Management in National GHG Inventories. IPCC 2000.

[7] IPCC (2006). 2006 IPCC Guidelines for National Greenhouse Gas Inventories.

[8] IPCC (2007), IPCC Fourth Assessment Report (AR4), Climate Change 2007: Working Group I: The Physical Science Basis.

[9] Kennedy, P.M., Milligan, L.P. (1978): Effects of cold exposure on digestion, microbial synthesis and nitrogen transformation in sheep. - British Journal of Nutrition 39:105-117.

[10] Lashof, D. A., Ahuja, D. R. (1990): Relative contributions of greenhouse gas emissions to global warming - Nature 344:529-531.

[11] Mosier, A.R., Duxbury, J.M., Freney, J.R., Heinemeyer, O., Minami, K., Johnson, D.E. (1998): Mitigating agricultural emissions of methane. - Climate Change 40:39-80.

[12] Murray, R.M., Bryant, A.M., Leng, R.A. (1976): Rate of production of methane in the rumen and the large intestine of sheep - British Journal of Nutrition 36:1-14.

[13] NIR (2014), Olecka, A., Bebkiewicz, K., Dębski, B., Jędrysiak, P., Kanafa, M., Kargulewicz, I., Rutkowski, J., Sędziwa, M., Skośkiewicz, J., Zasina, D., ZimakowskaLaskowska, M. (2014): Poland's National Inventory Report 2014. Greenhouse Gas Inventory for 1988-2012. Submission under the UN Framework Convention on Climate Change and its Kyoto Protocol. Reporting entity: National Centre for Emission Management (KOBiZE) at the Institute of Environmental Protection-National Research Institute. Warszawa.

[14] Oenema, O., Wrage, N., Velthof, G.L., van Groenigen, J.W., Dolfing, J., Kuikman, P.J. (2005): Trends in global nitrous oxide emissions from animal production systems Nutrient Cycling in Agroecosystems 72:51-65.

[15] Smith, K.A., Conen, F. (2004): Impacts of land management on fluxes of trace greenhouse gases - Soil Use and Management 20:255-263.

[16] Smith, P., D. Martino, Z. Cai, D. Gwary, H. Janzen, P. Kumar, B. McCarl, S. Ogle, F. O'Mara, C. Rice, B. Scholes, O. Sirotenko (2007): Agriculture. In Climate Change 2007: Mitigation. Contribution of Working Group III to the Fourth Assessment Report of the Intergovernmental Panel on Climate Change [B. Metz, O.R. Davidson, P.R. Bosch, R. Dave, L.A. Meyer (eds)] - Cambridge University Press, Cambridge, United Kingdom and New York, NY, USA.

[17] Wójcik-Gront, E., Gront, D. (2014): Assessing uncertainty in the Polish agricultural greenhouse gas emission inventory using Monte Carlo simulation - Outlook on Agriculture 43(1):61-65. 